\title{
Size distribution and elemental composition of ultrafine and nanoparticles
}

\author{
D. Bertolatti \& K. Rumchev \\ School of Public Health, Curtin University of Technology, Australia
}

\begin{abstract}
A large body of epidemiological research has found an association between increased particulate air pollution and acute and chronic respiratory symptoms.

One area of aerosol science that is currently of much interest, and is the focus of this article, is the formation of particles by combustion. Our major concern is with so-called "nanoparticles" (diameter less than $50 \mathrm{~nm}$ ), which can be formed, for example, from diesel engine and can be associated with health effects. One of the objectives of this pilot study was to characterize the NanoMoudi Model 125B which a second generation micro-orifice uniform deposit impactor. This new equipment is designed for sampling atmospheric aerosols and also for diesel emission monitoring and analysis. As part of this study the concentrations of particles with different size including $\mathrm{PM}_{10}, \mathrm{PM}_{2.5}$, and $\mathrm{PM}_{1.0}$ were also measured at different locations away from busy road within Perth metropolitan area using TSI DustTrak ${ }^{\text {TM }} 8520$ Aerosol Particulate Monitor and TSI P-Trak ${ }^{\circledR}$ 8525 Ultrafine Particle Counter.

The results of the study showed that the NanoMoudi could be used to successfully collect and analyze fine and ultrafine particles including diesel particulates. Further to this, people who lived closer to busy roads were more likely to be exposed to higher concentrations of ultrafine particles which could be associated with adverse health effects.
\end{abstract}

Keywords: ultrafine particles, diesel particles, NanoMoudi.

\section{Introduction}

Recently, ultrafine particles (diameter $<0.1 \mu \mathrm{m}$ ) have attracted significant scientific and medical attention since research shows that for equivalent masses of inhaled particles, ultrafine particles provide a greater surface area for 
adsorption of potentially toxic substances and metal agents. Further to this, ultrafine particles have also a higher deposition probability particularly in small airways and the alveolar region of the lungs than coarse particles. Ultrafine particles arise from multiple sources including vehicle and building exhaust, combustion processes, environmental tobacco smoke, and cleaning products. The particulate fraction of diesel exhaust consists mainly of very small particles (15$30 \mathrm{~nm}$ diameter) which rapidly agglomerate together to form "chains" and clumps of particles with size typically less than $1 \mu \mathrm{m}$ aerodynamic size [1]. High resolution electron microscopy has demonstrated that the basic diesel particulate particles consist of an irregular stacked graphitic structure, nominally called elemental carbon. The nature of these ultrafine particles allows them to absorb significant amount of organic carbon originating from unburnt fuel. With regards to health outcome, the small particle size of diesel particulate (DP) is considered as a significant health issue as it can penetrate deep in the lungs [2, 3]. In 1988, the National Institute of Occupational Safety and Health [4] (NIOSH) recommended that diesel exhaust be regarded as a "potential occupational carcinogen". Similarly, in 1989, the International Agency for Research on cancer declared, "diesel engine exhaust is probably carcinogenic to human" [5].

The aim of this pilot study was to characterize the second generation microorifice uniform deposit impactor, Model 125B NanoMoudi, in order to determine the best sampling strategy for collecting fine particles including diesel particles.

\section{Methodology}

In order to achieve the aim of the study and characterize the NanoMoudi a pilot study was conducted in two stages.

In stage one a heavy-duty diesel generator was used to collect diesel particulates using Nano-MOUDI (MSP Corp., MN). This is a micro-orifice uniform deposit impactor that traps airborne particles onto 13 individual collection filters with different sizes starting from $>10,000 \mathrm{~nm} 5,600 \mathrm{~nm}$, $3,200 \mathrm{~nm}, 1,800 \mathrm{~nm}, 1,000 \mathrm{~nm}, 560 \mathrm{~nm}, 320 \mathrm{~nm}, 180 \mathrm{~nm}, 100 \mathrm{~nm}, 56 \mathrm{~nm}, 32 \mathrm{~nm}$, $18 \mathrm{~nm}$ and $10 \mathrm{~nm}$. During this study each stage was loaded with pre-baked (at $550{ }^{\circ} \mathrm{C}$ ) uncoated aluminum foil substrates. The Nano-MOUDI was operated at a nominal flow rate of $10 \mathrm{l} / \mathrm{min}$ for multiple runs in order to accumulate sufficient mass for analysis. The Nano-MOUDI lower stage pressure drop was consistent $(\sim 12 \mathrm{mmHg})$ throughout the whole experimental campaign. Two tests were undertaken as during the first test the top two filters with size $10,000 \mathrm{~nm} 5,600 \mathrm{~nm}$ were coated with silicon while in the second testing no silicon was applied. The aim of these tests was to determine if coating with silicon could make an impact on particles collection.

During the second stage of this pilot study, atmospheric particulates with different size were collected at three different locations: $50 \mathrm{~m}, 100 \mathrm{~m}$ and $500 \mathrm{~m}$ away from a busy road within the Perth Metropolitan area. Samples were collected by the NanoMoudi Model 125B (results are not presented in this paper) and also by the real time aerosols monitor TSI DustTrak ${ }^{\mathrm{TM}} 8520$ Aerosol Particulate Monitor (TSI Incorporated, MN, USA). The DustTrak can measure 
particles concentration with size $10 \mu \mathrm{m}, 2.5 \mu \mathrm{m}$ and $0.1 \mu \mathrm{m}$. Number of ultrafine particles were also measured using the and TSI P-Trak ${ }^{\circledR} 8525$ Ultrafine Particle Counter. This portable instrument detects and counts ultrafine particles with size less than $1000 \mathrm{~nm}$.

\subsection{Sample analysis}

In this study both Zeiss Evo40 and Zeiss Neon40EsB scanning electron microscopes (SEM) using secondary as well as backscattered electron detectors were used in order to determine the sample morphology. The microscopes were coupled with an Oxford Instruments energy dispersive x-ray spectrometer (EDS) for qualitatively determining the elemental composition of particles.

\subsection{Statistical analysis}

Statistical analyses were performed with SPSS for Windows, version 18. All data was checked for normality. T- tests, Correlation, Chi-square analysis and OneWay Anova were performed to explore differences and associations between variables. In all statistical analysis, two-tailed tests were used and a 5\% level of significance was applied.
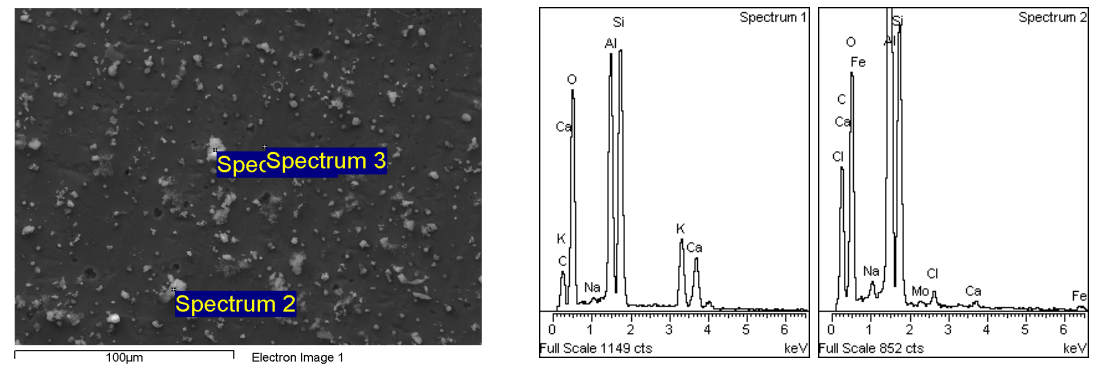

Figure 1: $\quad$ Scanning electron microscopy with elemental analysis, Stage 5 (particle size $\leq 1000 \mathrm{~nm}$ ), (uncoated).

\section{Results}

Pilot study - Stage I

The scanning electron microscopy was used to measure the proportions of total carbon and some other elements collected during the sampling period. Figs 1 and 2 present the sample analyses of filters from Stage 5 (particle size $\leq 1000 \mathrm{~nm}$ ) with and without the coating, respectively. As can been seen, a better elemental characterization was achieved and higher proportion of total carbon was collected on the filters without coating. Similar findings were observed for Stage 10 (with particle size $\leq 56 \mathrm{~nm}$ ). Figs 3 and 4 show that the main element detected by the electron microscopy was the total carbon. The sample analyses reveal the internal structure of the samples consisting of very fine particles clustered together. 

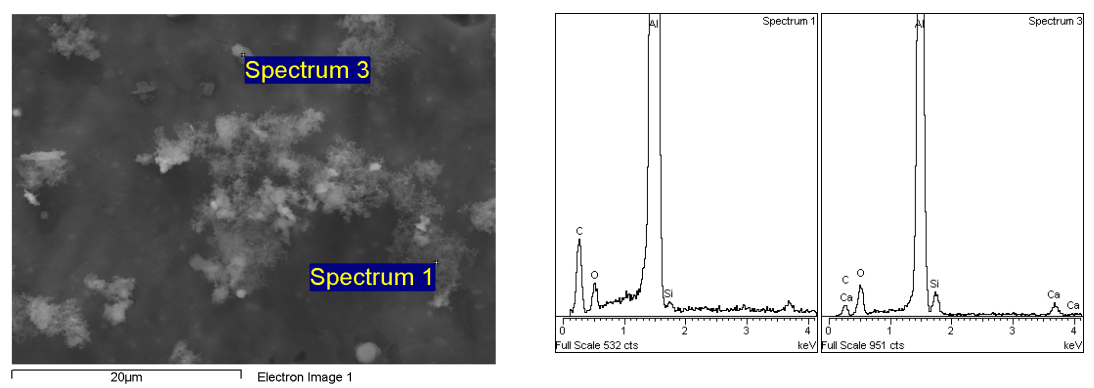

Figure 2: $\quad$ Scanning electron microscopy with elemental analysis, Stage 5 (particle size $\leq 1000 \mathrm{~nm})$, (coated).
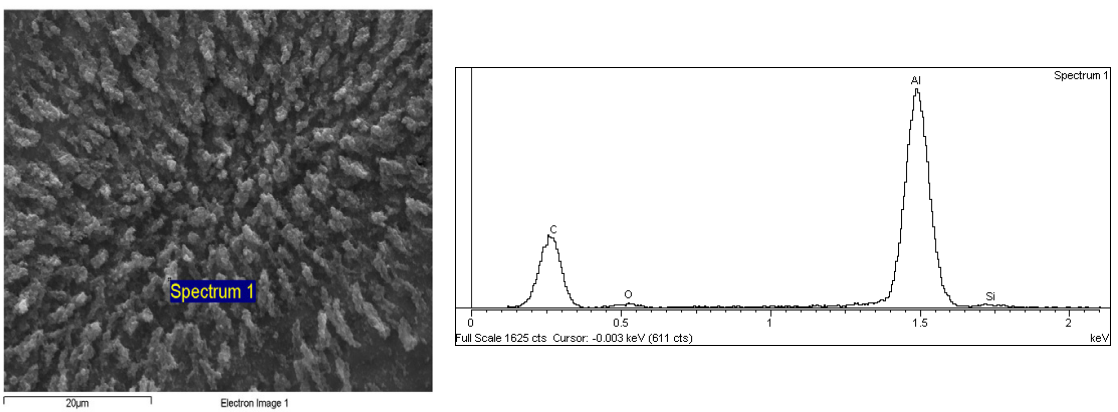

Figure 3: Scanning electron microscopy with elemental analysis, Stage 10 (particle size $\leq 56 \mathrm{~nm}$ ), (coated).
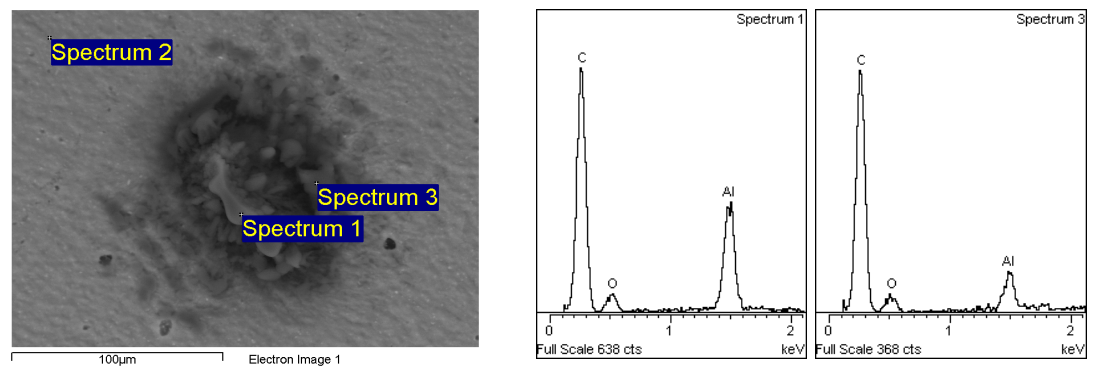

Figure 4: $\quad$ Scanning electron microscopy with elemental analysis, Stage 10 (particle size $\leq 56 \mathrm{~nm}$ ) (uncoated).

Figure 5 and 6 present the electron microscopy of stage 11 which represent the nano particle range with size $\leq 32 \mathrm{~nm}$. It appears that clusters that were observed on Stage 5 and 10 have been transformed into tiny liquid particles coalescing after impaction. These very fine particles are empty on the inside so their aerodynamic diameter is really much smaller that the geometric diameter. 

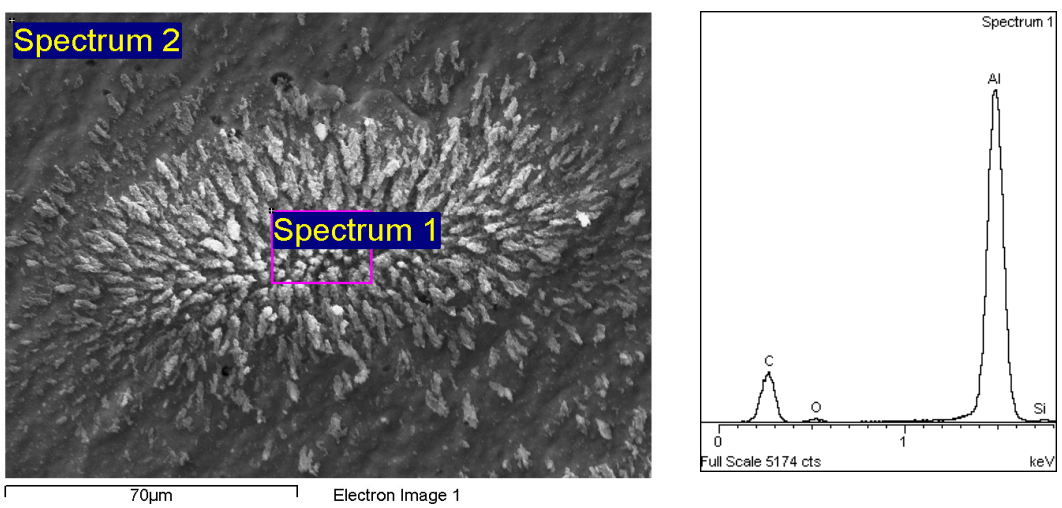

Figure 5: $\quad$ Scanning electron microscopy with elemental Analysis, Stage 11 (particle size $\leq 32 \mathrm{~nm}$ ), (uncoated).

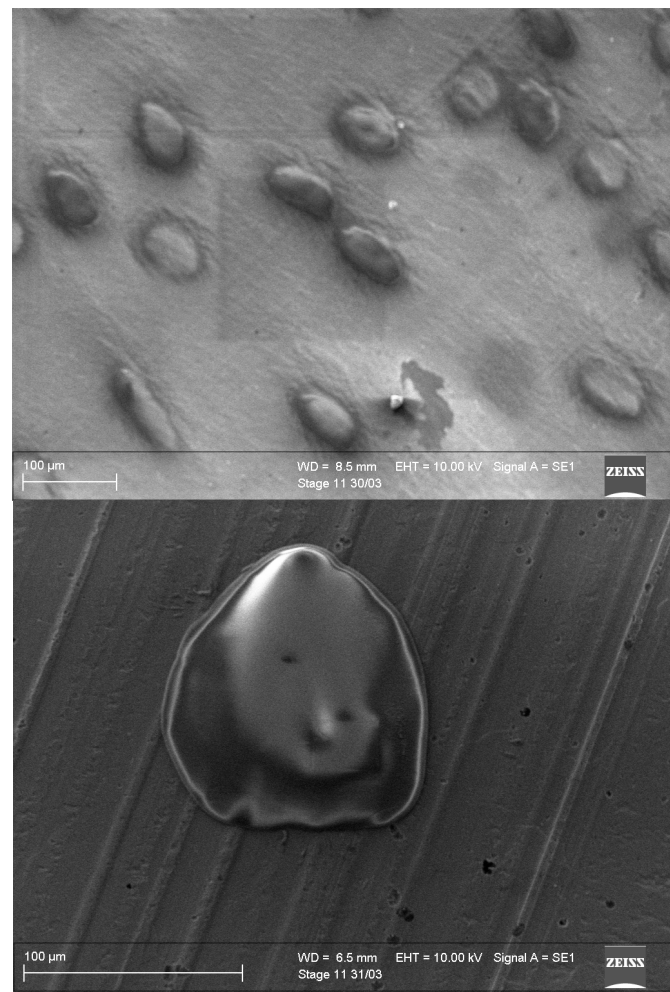

Figure 6: Scanning electron microscopy with elemental analysis Stage 11 (particle size $\leq 32 \mathrm{~nm}$ ), (uncoated). 
Pilot study - Stage II

Table 1 shows the concentrations and number of particulates collected from three different locations $50 \mathrm{~m}, 100 \mathrm{~m}$ and $500 \mathrm{~m}$ away from busy roads. The sampling was conducted in March, 2009 in the Perth Metropolitan area.

Table 1: Mean concentrations and number of particulate matter at $50 \mathrm{~m}$, $100 \mathrm{~m}$ and $500 \mathrm{~m}$ away from busy roads.

\begin{tabular}{|c|c|c|c|c|}
\hline $\begin{array}{l}\text { Particle } \\
\text { size }\end{array}$ & $\begin{array}{c}50 \mathrm{~m} \\
\text { (Range) }\end{array}$ & $\begin{array}{l}100 \mathrm{~m} \\
\text { (Range) }\end{array}$ & $\begin{array}{c}500 \mathrm{~m} \\
\text { (Range) }\end{array}$ & $P$ value \\
\hline $\mathrm{PM}_{1.0}$ & $\begin{array}{l}49 \mu \mathrm{g} / \mathrm{m}^{3} \\
\left(9 \mu \mathrm{g} / \mathrm{m}^{3}-189 \mu \mathrm{g} / \mathrm{m}^{3}\right)\end{array}$ & $\begin{array}{l}21 \mu \mathrm{g} / \mathrm{m}^{3} \\
\left(3 \mu \mathrm{g} / \mathrm{m}^{3}-56 \mu \mathrm{g} / \mathrm{m}^{3}\right)\end{array}$ & $\begin{array}{l}16.3 \mu \mathrm{g} / \mathrm{m}^{3} \\
\left(2 \mu \mathrm{g} / \mathrm{m}^{3}-107 \mu \mathrm{g} / \mathrm{m}^{3}\right.\end{array}$ & 0.000 \\
\hline $\mathrm{PM}_{2.5}$ & $\begin{array}{l}127 \mu \mathrm{g} / \mathrm{m}^{3} \\
\left(16 \mu \mathrm{g} / \mathrm{m}^{3}-185 \mu \mathrm{g} / \mathrm{m}^{3}\right)\end{array}$ & $\begin{array}{l}20 \mu \mathrm{g} / \mathrm{m}^{3} \\
\left(3 \mu \mathrm{g} / \mathrm{m}^{3}-84 \mu \mathrm{g} / \mathrm{m}^{3}\right)\end{array}$ & $\begin{array}{l}7.7 \mu \mathrm{g} / \mathrm{m}^{3} \\
2 \mu \mathrm{g} / \mathrm{m}^{3}-67 \mu \mathrm{g} / \mathrm{m}^{3}\end{array}$ & 0.000 \\
\hline $\mathrm{PM}_{10}$ & $\begin{array}{l}20.2 \mu \mathrm{g} / \mathrm{m}^{3} \\
\left(4 \mu \mathrm{g} / \mathrm{m}^{3}-67 \mu \mathrm{g} / \mathrm{m}^{3}\right)\end{array}$ & $\begin{array}{l}18 \mu \mathrm{g} / \mathrm{m}^{3} \\
\left(2 \mu \mathrm{g} / \mathrm{m}^{3}-39 \mu \mathrm{g} / \mathrm{m}^{3}\right)\end{array}$ & $\begin{array}{l}5.1 \mu \mathrm{g} / \mathrm{m}^{3} \\
\left(3 \mu \mathrm{g} / \mathrm{m}^{3}-13 \mu \mathrm{g} / \mathrm{m}^{3}\right)\end{array}$ & 0.000 \\
\hline $\begin{array}{l}\text { Ultrafine } \\
\text { particle } \\
\text { numbers }\end{array}$ & $\begin{array}{l}8576.3 \\
(4923-23963)\end{array}$ & $\begin{array}{l}8567.2 \\
(5746-15125)\end{array}$ & $\begin{array}{l}6584 \\
(4449-8526)\end{array}$ & 0.000 \\
\hline
\end{tabular}

Table 2: Comparison of the mean concentrations of particulate matter between weekdays and weekends.

\begin{tabular}{|c|c|c|c|}
\hline $\begin{array}{l}\text { Particulate } \\
\text { Matter }\end{array}$ & $\begin{array}{l}\text { Weekdays } \\
\text { (Range) }\end{array}$ & $\begin{array}{l}\text { Weekend } \\
\text { (Range) }\end{array}$ & p-value \\
\hline $\mathrm{PM}_{1.0}(50 \mathrm{~m})$ & $\begin{array}{l}49 \mu \mathrm{g} / \mathrm{m}^{3} \\
\left(9 \mu \mathrm{g} / \mathrm{m}^{3}-189 \mu \mathrm{g} / \mathrm{m}^{3}\right)\end{array}$ & $\begin{array}{l}3.9 \mu \mathrm{g} / \mathrm{m}^{3} \\
\left(2 \mu \mathrm{g} / \mathrm{m}^{3}-27 \mu \mathrm{g} / \mathrm{m}^{3}\right)\end{array}$ & 0.000 \\
\hline $\mathrm{PM}_{2.5}(50 \mathrm{~m})$ & $\begin{array}{l}127 \mu \mathrm{g} / \mathrm{m}^{3} \\
\left(16 \mu \mathrm{g} / \mathrm{m}^{3}-185 \mu \mathrm{g} / \mathrm{m}^{3}\right)\end{array}$ & $\begin{array}{l}2.8 \mu \mathrm{g} / \mathrm{m}^{3} \\
\left(2 \mu \mathrm{g} / \mathrm{m}^{3}-8 \mu \mathrm{g} / \mathrm{m}^{3}\right)\end{array}$ & 0.000 \\
\hline $\mathrm{PM}_{10}(50 \mathrm{~m})$ & $\begin{array}{l}20.2 \mu \mathrm{g} / \mathrm{m}^{3} \\
\left(4 \mu \mathrm{g} / \mathrm{m}^{3}-67 \mu \mathrm{g} / \mathrm{m}^{3}\right)\end{array}$ & $\begin{array}{l}6.1 \mu \mathrm{g} / \mathrm{m}^{3} \\
\left(3 \mu \mathrm{g} / \mathrm{m}^{3}-35 \mu \mathrm{g} / \mathrm{m}^{3}\right)\end{array}$ & 0.001 \\
\hline $\mathrm{PM}_{1.0}(100 \mathrm{~m})$ & $\begin{array}{l}21 \mu \mathrm{g} / \mathrm{m}^{3} \\
\left(3 \mu \mathrm{g} / \mathrm{m}^{3}-56 \mu \mathrm{g} / \mathrm{m}^{3}\right)\end{array}$ & $\begin{array}{l}3.9 \mu \mathrm{g} / \mathrm{m}^{3} \\
\left(2 \mu \mathrm{g} / \mathrm{m}^{3}-30 \mu \mathrm{g} / \mathrm{m}^{3}\right)\end{array}$ & 0.000 \\
\hline $\mathrm{PM}_{2.5}(100 \mathrm{~m})$ & $\begin{array}{l}20 \mu \mathrm{g} / \mathrm{m}^{3} \\
\left(3 \mu \mathrm{g} / \mathrm{m}^{3}-84 \mu \mathrm{g} / \mathrm{m}^{3}\right)\end{array}$ & $\begin{array}{l}6.3 \mu \mathrm{g} / \mathrm{m}^{3} \\
\left(4 \mu \mathrm{g} / \mathrm{m}^{3}-8 \mu \mathrm{g} / \mathrm{m}^{3}\right)\end{array}$ & 0.000 \\
\hline $\mathrm{PM}_{10}(100 \mathrm{~m})$ & $\begin{array}{l}18 \mu \mathrm{g} / \mathrm{m}^{3} \\
\left(2 \mu \mathrm{g} / \mathrm{m}^{3}-39 \mu \mathrm{g} / \mathrm{m}^{3}\right)\end{array}$ & $\begin{array}{l}4.9 \mu \mathrm{g} / \mathrm{m}^{3} \\
\left(4 \mu \mathrm{g} / \mathrm{m}^{3}-8 \mu \mathrm{g} / \mathrm{m}^{3}\right)\end{array}$ & 0.000 \\
\hline
\end{tabular}

There was a strong and significant $(\mathrm{p}<0.05)$ correlation between particle concentrations and number of particles with the temperature and relative humidity.

Concentrations of particulate matter with different size were also measured during weekends and in Table 2 are presented the exposure levels of particulate matter with different size measured during weekends and weekdays. As can be seen significantly higher concentrations were recorded during weekdays. 


\section{Discussion and conclusion}

A NanoMoudi 125B was used to collect diesel particles from a heavy-duty diesel generator. Morphology and qualitative elemental composition were determined by Scanning Electron Microscopy (SEM). This study showed that NanoMoudi impactor made it possible to successfully collect and analyse particles. This equipment also collected particles not larger than the largest filter size which can provide a reliable particle size distribution. The pilot study also demonstrated that NanoMoudi can be used to collect diesel particles. The sample analyses showed that a much greater concentration of carbon particles was observed in the nanosize range (Stage 10) compared to the larger particle size range (Stages 5). This is consistent with the literature as according to Sharp [6] nearly all diesel particulates fall into the fine particle size range $\left(\mathrm{PM}_{2.5}\right)$ with $50-90 \%$ of the total number of particles falling into the ultra-fine particle size range (aerodynamic diameter of less than $0.1 \mu \mathrm{m})$.

As mentioned earlier, during the sample preparation, all aluminum foils were baked at $500^{\circ} \mathrm{C}$, however, it was observed that heat treating filters to $500^{\circ} \mathrm{C}$ could create pores in them which could cause problems with particle collection. Recommendations were made that heat treatment to $100^{\circ} \mathrm{C}$ would be more appropriate.

The second stage of the present study measured the concentrations of particles with different size near busy roads. This investigation showed that people who lived near busy roads in Perth Metropolitan area are more likely to be exposed to higher concentrations of fine and ultrafine particles, including diesel particulates which could be associated with the development of adverse health effects. This is consistent with other studies stating that emissions form diesel-powered engines are the most significant contributor to urban air pollution worldwide [1].

\section{References}

[1] Walsh M.P. "Global Trends in Diesel Emission Control: A 2000 Update". September, 2000. [Online] Available at www.walshcarlines.com/pdf /sae2000.pdf

[2] Health Effects Institute. "Diesel Exhaust: A Critical Analysis of Emissions, Exposures, and Health Effects". A Special Report of the Institute's Working Group. Health Effects Institute, pp. 294, (1995).

[3] Pope, A., Burnett, R., Thun, M., et al.. "Lung Cancer, Cardiopulmonary Mortality, and Long-term Exposure to Fine Particulate Air Pollution". Jour. of Amer. Med. Ass. 287(9):1132-1141, (2002).

[4] National Institute of Occupational Safety and Health (NIOSH). "Carcinogenic Effects of Exposure to Diesel Exhaust". CIB 50, pp. 30,Cincinnati, Ohio, (1988). 
54 Environmental Health Risk V

[5] International Agency for Research on Cancer. "Monographs on the Evaluation of Carcinogenic Risks to Humans Diesel and Gasoline Engine Exhausts and Some Nitroarenes". 46: pg. 458, Lyon, France, (1989).

[6] Sharp J. 2004. The public impact of Diesel Particulate Matter. Sierra Club of Canada. http://eastern.sierraclub.ca/pdf/ ExecutiveSummary.pdf. 